\section{TOWARD THE \\ YEAR 2000}

Work in Progress

edited by Daniel Bell

and Stephen R. Graubard

Important for its intellectual energy and for its insightful sharpness into the nature of American society, this reissue of a classic of futurism (first published in 1967) also assesses the original project, which commissioned the views of eminent thinkers on the future.

412 pp. $\$ 17.50$ paper

\section{Now available in paperback}

\section{HANNAH ARENDT}

\section{Twenty Years Later}

edited by Larry May and Jerome Kohn

"[P]rovides innovative and provocative readings and re-readings of significant aspects of Arendt's work." - Lisa J. Disch, University of Minnesota

Studies in Contemporary German Social Thought 400 pp. $\$ 17.50$ paper

\section{Original in Paperback}

\section{PERPETUAL PEACE}

\section{Essays on Kant's \\ Cosmopolitan Ideal \\ edited by James Bohman \\ and Matthias Lutz-Bachmann}

Explores the continuing importance of "cosmopolitanism" in the quest for world peace.

Studies in contemporary German Social Thought - 272 pp. $\$ 17.50$ paper

\section{Original In Paperback}

DELIBERATIVE DEMOCRACY

Essays on Reason and Polltics edited by James Bohman and William Rehg

Investigates the idea that legitimate lawmaking issues from the public deliberation of citizens.

480 pp. $\$ 25$ paper (January) 


\section{O Journal of Applied Philosophy}

Journal of the Society for Applied Philosophy

Edited by Stephen Clark and Brenda Almond

The Journal of Applied Philosophy provides a unique forum for philosophical research, linking an audience of professional and non-professional philosophers. Open to the expression of diverse viewpoints, the journal applies critical analysis to areas of practical concern as well as directly exploning questions of value. The journal covers a broad spectrum of issues such as the environment, medicine, science policy, law and education.

\section{ORDER FORM}

Joumal of Appliod Philosophy

Subseription Rales, Volume 14/1997

ISSN 0264-3758

Published in: Jonuary, May and September

Institutional Rates, $\{135.00$ (UK-Europe), $\$ 213.00$ (N. Americo), $\$ 135.00$ (Rest of World)

Personal Rotes, $\$ 53.00$ (UK-Europe), $\$ 84.00$ (N. America), $\$ 53.00$ (Rest of World)

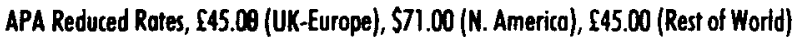

$\square$ Please enter my subsaription/send me a sample copy

$\square$ I enclose a cheque/money order poyable to Blackwell Publishers

$\square$ Please charge my American Express/Diners Club/Mastercard/Nisa account

Cord Number Expin Date.

Signature. Dote

Nome.

Address

Postcode

Payment must accompany orders

Pleose return this form to:

Journals Marketing, Blackwell Publishers, 108 Cowley Rood, Oxford, OX4 UJF, UK.

Or 10: Journals Markering, JAPP, Blackwell Publishers, 350 Main Street, Malden, MA 02148, USA.

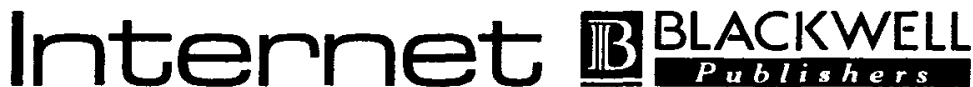

For more information, or to order a free sample copy, visit our website 


\section{Social Philosophy \\ \& Policy}

ISSN 0265-0525

Editorial Office: Social Philosophy and Policy Center, Bowling Green State University, Bowling Green, OH 43403, USA.

Publishing, Subscription, and Advertising Offices: Cambridge University Press, 40 West 20th Street, New York, NY 10011, USA; or (outside the USA and Canada) Cambridge University Press, The Edinburgh Building, Shaftesbury Road, Cambridge CB2 2RU, England.

Subscription Information: Social Philosophy \& Policy is published biannually, in Winter and Summer. Annual subscription rates for Volume 15 (1998): Institutional, US $\$ 89.00$ in the USA, Canada, and Mexico; UK $£ 60.00+$ VAT elsewhere. Individual, US $\$ 35.00$ in the USA, Canada, and Mexico; UK $£ 23.00+$ VAT elsewhere. Single parts, US $\$ 46.00$ in the USA, Canada, and Mexico; UK $£ 33.00$ + VAT elsewhere. Prices include postage and insurance.

Back Issues: For information on purchase of back issues, contact Cambridge University Press.

Issues on Microfilm: An arrangement for the supply of microfilm copies of Social Philosophy \& Policy from Volume 1 onward has been made with University Microfilms International, Dept. P.R., 30-32 Mortimer Street, London W1N 7RA, England; and 300 North Zeeb Road, Ann Arbor, MI 48106, USA.

Indexing and Abstracting: Social Philosophy $\mathcal{E}$ Policy is indexed and abstracted in Applied Social Science Index and Abstracts, Automatic Subject Citation Alert, International Political Science Abstracts, Linguistics and Language Behavior Abstracts, Philosopher's Index, and the Ethics Index. 


\section{Social Philosophy \& Policy}

\section{Themes of Past and Forthcoming Issues}

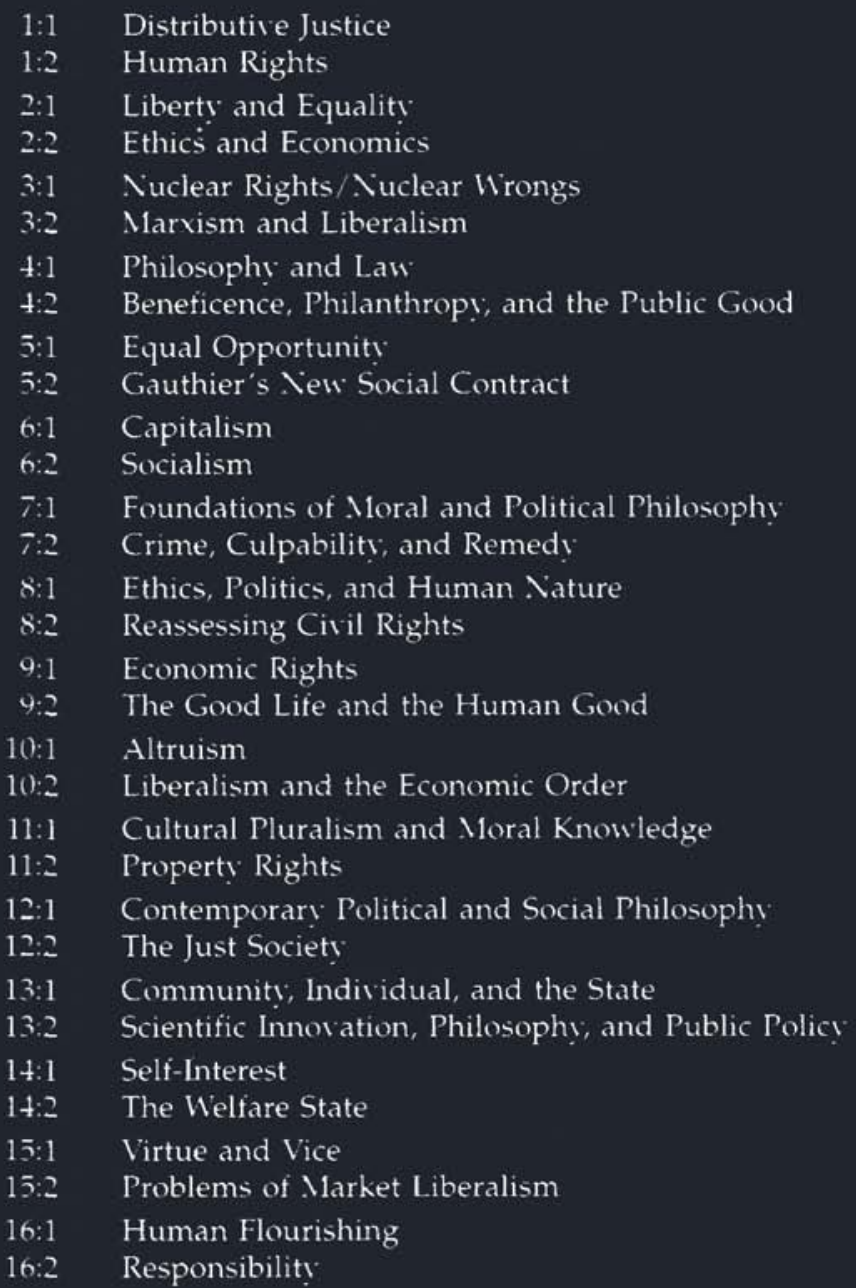

See inside back cover for information on ordering subscriptions or single copies

Copyright c 1998 Social Philosophy and Policy Foundation 